\title{
Effects of anesthetic agents on inflammation in Caco-2, HK-2 and HepG2 cells
}

\author{
WEIJING LI ${ }^{1 *}$, XIAOGUANG HAO ${ }^{2 *}$, YAN LIU ${ }^{1}$, TONG TONG ${ }^{1}$, HONGMENG XU $^{1}$ and LI JIA ${ }^{1}$ \\ Departments of ${ }^{1}$ Anesthesiology and ${ }^{2}$ Radiology, The Fourth Hospital of Hebei Medical University, \\ Shijiazhuang, Hebei 050000, P.R. China
}

Received June 15, 2020; Accepted November 2, 2020

DOI: $10.3892 /$ etm.2021.9918

\begin{abstract}
Anesthetic agents are often used in surgical procedures to relieve pain in patients with traumatic injuries. Several anesthetic agents can cause immunosuppression by suppressing the secretion of immune factors such as cytokines. However, the effects of different anesthetic agents on inflammation are not completely understood. In the present study, three cell lines, Caco-2, HK-2 and HepG2, were treated with five anesthetic agents, including sodium barbiturate, midazolam, etomidate, ketamine and propofol, to investigate the effects of different anesthetic agents on inflammation in in vitro models. The expression levels of inflammatory genes, including $\mathrm{NF}-\kappa \mathrm{B}$ and its downstream cytokines, were detected via reverse transcription-quantitative PCR. The results indicated that anesthetic agents, including sodium barbiturate, ketamine and propofol, but not midazolam and etomidate, exerted significant inhibitory effects on $\mathrm{NF}-\kappa \mathrm{B}$ expression in the three different cell lines. Sodium barbiturate, ketamine and propofol also decreased the expression levels of the NF- $\kappa \mathrm{B}$ downstream cytokines, including IL-1 $\beta$ and IL-18. Moreover, sodium barbiturate, ketamine and propofol reduced the effect of TNF- $\alpha$ on inflammatory activity in the three cell lines. The results of the present study may provide novel insight into the effects of anesthetic agents on inflammation and may aid with selecting the most appropriate anesthetic agent in surgical procedures.
\end{abstract}

\section{Introduction}

Anesthetic agents serve an important role in relieving pain in patients with traumatic injuries and in surgical procedures, but managing the utilization of anesthetic agents is a challenge for

Correspondence to: Dr Xiaoguang Hao, Department of Radiology, The Fourth Hospital of Hebei Medical University, 12 Ji'an'kang Road, Shijiazhuang, Hebei 050000, P.R. China

E-mail: haoxiaoguang566@163.com

${ }^{*}$ Contributed equally

Key words: anesthetic agents, inflammation, Caco-2, HK-2, HepG2 the anesthesiologist (1). A variety of anesthetic agents have been developed, including volatile anesthetics, nitrous oxide, xenon, propofol, ketamine, etomidate, dexmedetomidine, opioids, benzodiazepines, barbiturates, lidocaine and regional anesthesia (1). Different anesthetic agents exert distinct biological and physiological functions in the body, whereas determining the molecular and cellular functions of anesthetic agents is a challenge due to their pleiotropic effect (2). Besides their anesthetic effects, a number of anesthetic agents exert other functions, such as antimicrobial effects (3), synaptic inhibition (4), disruption of brain circuit formation (5) and left ventricular systolic function (ketamine and xylazine increasing the left ventricular ejection fraction and decreasing the left ventricular end diastolic diameter) (6). It has also been reported that certain anesthetic agents display cytotoxicity, neurotoxicity and genotoxicity (7). Inflammation is an innate physiological process in the body, which may have both favorable and unfavorable consequences for an individual's health. Inflammation protects against harmful pathogens and is activated during acute and chronic diseases (8). Inflammation is a complex biological network that involves a number of transcription factors, including NF- $\mathrm{B}$ and STAT3, inflammatory enzymes and inflammatory cytokines (8). The NF- $\kappa \mathrm{B}$ signaling pathway serves a central role in regulating inflammation, and functions in various organs and tissues. Emerging evidence indicates that inflammation is related to surgical processes, which should be considered during the management of surgery. For example, if trauma-induced inflammation is not appropriately regulated, neuro-inflammation may interfere with synaptic plasticity to affect learning and memory aspects of cognition (9). By contrast, surgical manipulation causes stress responses, inhibits immune cells and suppresses cell-mediated immunity (10). Increasing evidence indicates that anesthetic agents regulate immune reactions in the body (11). Therefore, the optimal choice of anesthetic agents serves an important role in health management during surgery. However, how anesthetic agents affect the immune system is not completely understood.

It has been reported that several anesthetic agents exert immunosuppressive functions by suppressing the viability of immune cells (11). Different anesthetic agents exert different effects on a variety of immune cells, for example, ketamine and thiopental, but not propofol, inhibit natural killer cells, whereas ketamine, but not midazolam, causes T-lymphocyte 
apoptosis (11). Investigating the effects of different anesthetic agents on inflammation is important due to the link between surgery and inflammation, and understanding this link is important for regulating the effects of anesthetic agents on inflammation (10).

The present study aimed to investigate the effects of five anesthetic agents, including sodium barbiturate, midazolam, etomidate, ketamine and propofol, on inflammation in three cell lines (Caco-2, HK-2 and HepG2). The results of the present study may aid with choosing the suitable anesthetic agent for surgical procedures.

\section{Materials and methods}

Study design. To investigate the effects of various commonly used anesthetic agents on different cell lines, five commonly used anesthetic agents including sodium barbiturate, midazolam, etomidate, ketamine and propofol at different concentrations were used to treat Caco-2 (intestine), HK-2 (kidney) and HepG2 (liver) cells. Caco-2 cell line is a continuous line of heterogeneous human epithelial colorectal adenocarcinoma cells, which has been used for intestine studies $(12,13)$. HK-2 cell line is an immortalized proximal tubular cell line derived from normal kidney, which has been widely used for kidney studies $(14,15)$. HepG2 is a liver cancer cell line, which has been used for liver studies $(16,17)$. Reverse transcription-quantitative PCR (RT-qPCR) and western blotting assays were used to determine the expression levels of $\mathrm{NF}-\kappa \mathrm{B}$ and its downstream cytokines in cells treated with different anesthetic agents.

Chemicals and drugs. The following anesthetic agents were used: Sodium barbiturate $\left[\mathrm{C}_{4} \mathrm{H}_{3} \mathrm{~N}_{2} \mathrm{NaO}_{3}\right.$; molecular weight, $150.07 \mathrm{~g} / \mathrm{mol}$; Chemical Abstracts Service (CAS) no. 4390-16-3], midazolam $\left(\mathrm{C}_{18} \mathrm{H}_{13} \mathrm{ClFN}_{3}\right.$; molecular weight, $325.77 \mathrm{~g} / \mathrm{mol}$; CAS no. 59467-70-8), etomidate $\left(\mathrm{C}_{14} \mathrm{H}_{16} \mathrm{~N}_{2} \mathrm{O}_{2}\right.$; molecular weight, 244.29; CAS no. 33125-97-2), ketamine $\left(\mathrm{C}_{13} \mathrm{H}_{17} \mathrm{Cl}_{2} \mathrm{NO}\right.$; molecular weight, 274.19; CAS no. 1867-66-9) and propofol $\left[\left(\mathrm{CH}_{3}\right)_{2} \mathrm{CH}_{2} \mathrm{C}_{6} \mathrm{H}_{3} \mathrm{OH}\right.$; molecular weight, 178.27; CAS no. 2078-54-8]. All chemicals were supplied by Sigma-Aldrich; Merck KGaA, diluted according to manufacturer's instruction, aliquoted and frozen at $-80^{\circ} \mathrm{C}$ prior to use. Control groups were non-treated cells.

Cell culture. Caco-2, HK-2 and HepG2 cells were purchased from American Type Culture Collection and cryopreserved until use. After thawing, cells were sub-cultured at least twice prior to experimental use. All cells were cultured according to manufacturer's instructions. Briefly, cells were cultured in DMEM (cat. no. 10567014; Thermo Fisher Scientific, Inc.) supplemented with $10 \%$ (v/v) FBS (Invitrogen; Thermo Fisher Scientific, Inc.) and $1 \%$ penicillin-streptomycin (cat. no. 15140163; Thermo Fisher Scientific, Inc.). The culture medium was refreshed every 3 days. Cells were maintained at $37^{\circ} \mathrm{C}$ with $5 \% \mathrm{CO}_{2}$ in a humidified atmosphere and routinely sub-cultured twice a week at $70-80 \%$ confluence using $0.5 \%$ trypsin-EDTA (cat. no. 25200072; Thermo Fisher Scientific, Inc.).

Drug treatment. At $>90 \%$ confluence in T75 flasks, cells were dissociated using TrpyLE (cat. no. 12604013; Thermo Fisher Scientific, Inc.) and seeded into 48 -well plates $\left(2.5 \times 10^{4}\right.$ cell per well). At $30-40 \%$ confluence, cells were treated with 0 , $0.1,1.0,2.0,5.0$ or $10.0 \mu \mathrm{M}$ sodium barbiturate, midazolam, etomidate, ketamine or propofol for $48 \mathrm{~h}$ at $37^{\circ} \mathrm{C}$ with $5 \% \mathrm{CO}_{2}$ in a humidified atmosphere. The doses of drugs were selected based on the clinical experience of the authors. A previous study indicated that the plasma concentration of barbiturate should be below $4.4 \mu \mathrm{g} / \mathrm{ml}(\sim 24 \mu \mathrm{M}$; measured on the day when burst-suppression pattern had disappeared) (18). In addition, concentration of midazolam in patients was between 20 and $100 \mu \mathrm{M}$ (blood was collected at 30-45 min before the patient came to the operating room) (19), the steady state plasma concentration of etomidate was $158 \mu \mathrm{g} / 1(\sim 0.65 \mu \mathrm{M}$; measured for periods of up to $24 \mathrm{~h}$ after stopping the infusion) (20), the plasma concentration of ketamine at steady-state was $1,018.7 \mathrm{ng} / \mathrm{ml}(\sim 4.29 \mu \mathrm{M}$; the average of the three plasma samples collected at 20,42, and 54 half-lives during continuous infusion) (21) and the concentration of propofol was 4-6 $\mu \mathrm{g} / \mathrm{l}$ (22.50-33.75 $\mu \mathrm{M}$; the time point of the measurement was not mentioned) (22). According to the aforementioned clinical studies, the plasma concentration of anesthetic agents should be between 0.65 to $33.75 \mu \mathrm{M}$. In combination with the experience of the current authors, the maximum concentration of the anesthetic agents used was $10.0 \mu \mathrm{M}$

For the co-treatment of TNF $\alpha(100 \mathrm{nM})$ and anesthetic agents $(10 \mu \mathrm{M})$ including sodium barbiturate, ketamine and propofol, cells were treated with a cocktail of $\mathrm{TNF} \alpha$ and sodium barbiturate, $\mathrm{TNF} \alpha$ and ketamine, and $\mathrm{TNF} \alpha$ and propofol for $48 \mathrm{~h}$ at $37^{\circ} \mathrm{C}$ with $5 \% \mathrm{CO}_{2}$ in a humidified atmosphere. Medium without any drugs was set as the control.

RNA isolation and RT-qPCR. Total RNA from cells including Caco-2, HK-2 and HepG2 cells was isolated using the RNAeasy ${ }^{\mathrm{TM}}$ kit (Beyotime Institute of Biotechnology) according to the manufacturer's protocol. Total RNA was eluted with nuclease-free water and treated with DNase I (Invitrogen; Thermo Fisher Scientific, Inc.). Subsequently, total RNA $(1 \mu \mathrm{g})$ was reverse transcribed into cDNA using the ReverTra Ace ${ }^{\circledR}$ RT system (Toyobo Life Science) according to the manufacturer's protocol. qPCR was performed using the iCycler iQ system (Bio-Rad Laboratories, Inc.) and IQ SYBR Green Supermix (Bio-Rad Laboratories, Inc.). The following thermocycling conditions were used for the qPCR: Initial denaturation at $95^{\circ} \mathrm{C}$ for $5 \mathrm{~min}$; 40 cycles of $95^{\circ} \mathrm{C}$ for $15 \mathrm{sec}$ and $60^{\circ} \mathrm{C}$ for $35 \mathrm{sec}$. The sequences of the primers used for qPCR are presented in Table I. The primers were designed using NCBI Pick Primers (https://www.ncbi.nlm.nih. gov/tools/primer-blast/) and manufactured by Sangon Biotech Co., Ltd. The mRNA expression levels were quantified using the $2^{-\Delta \Delta \mathrm{Cq}}$ method and normalized to the internal reference gene GAPDH according to a previous study (12). RT-qPCR was performed in triplicate.

Western blot analysis. Caco-2, HK-2 and HepG2 cells treated with $10 \mu \mathrm{M}$ sodium barbiturate, ketamine and propofol were lysed using radioimmunoprecipitation assay lysis buffer (Beyotime Institute of Biotechnology) for $30 \mathrm{~min}$ on ice. The supernatant was aspirated for the determination of protein concentration using a bicinchoninic acid assay kit, after centrifugation at $1,500 \mathrm{x} \mathrm{g}$ and $4^{\circ} \mathrm{C}$ for $10 \mathrm{~min}$. The samples were heated for $10 \mathrm{~min}$ at $95^{\circ} \mathrm{C}$. Afterwards, the samples $(30 \mu \mathrm{g} / \mathrm{lane})$ 
Table I. Primers for reverse transcription-quantitative PCR.

\begin{tabular}{|c|c|c|}
\hline Primer & Sequence $\left(5^{\prime}-3^{\prime}\right)$ & Product size, nt \\
\hline \multirow[t]{2}{*}{$\mathrm{NF}-\kappa \mathrm{B}$} & F: ACAGCGGGGAAAGACACATC & 221 \\
\hline & R: TCTGCCATTCTGAAGCTCTCTC & \\
\hline \multirow[t]{2}{*}{ IL-1B } & F: AGCCATGGCAGAAGTACCTG & 116 \\
\hline & R: CCTGGAAGGAGCACTTCATCT & \\
\hline \multirow[t]{2}{*}{ IL-18 } & F: TGCAGTCTACACAGCTTCGG & 99 \\
\hline & R: GCAGCCATCTTTATTCCTGCG & \\
\hline \multirow[t]{2}{*}{ GAPDH } & F: AATGGGCAGCCGTTAGGAAA & 166 \\
\hline & R: GCCCAATACGACCAAATCAGAG & \\
\hline
\end{tabular}

F, forward; R, reverse; nt, nucleotides.
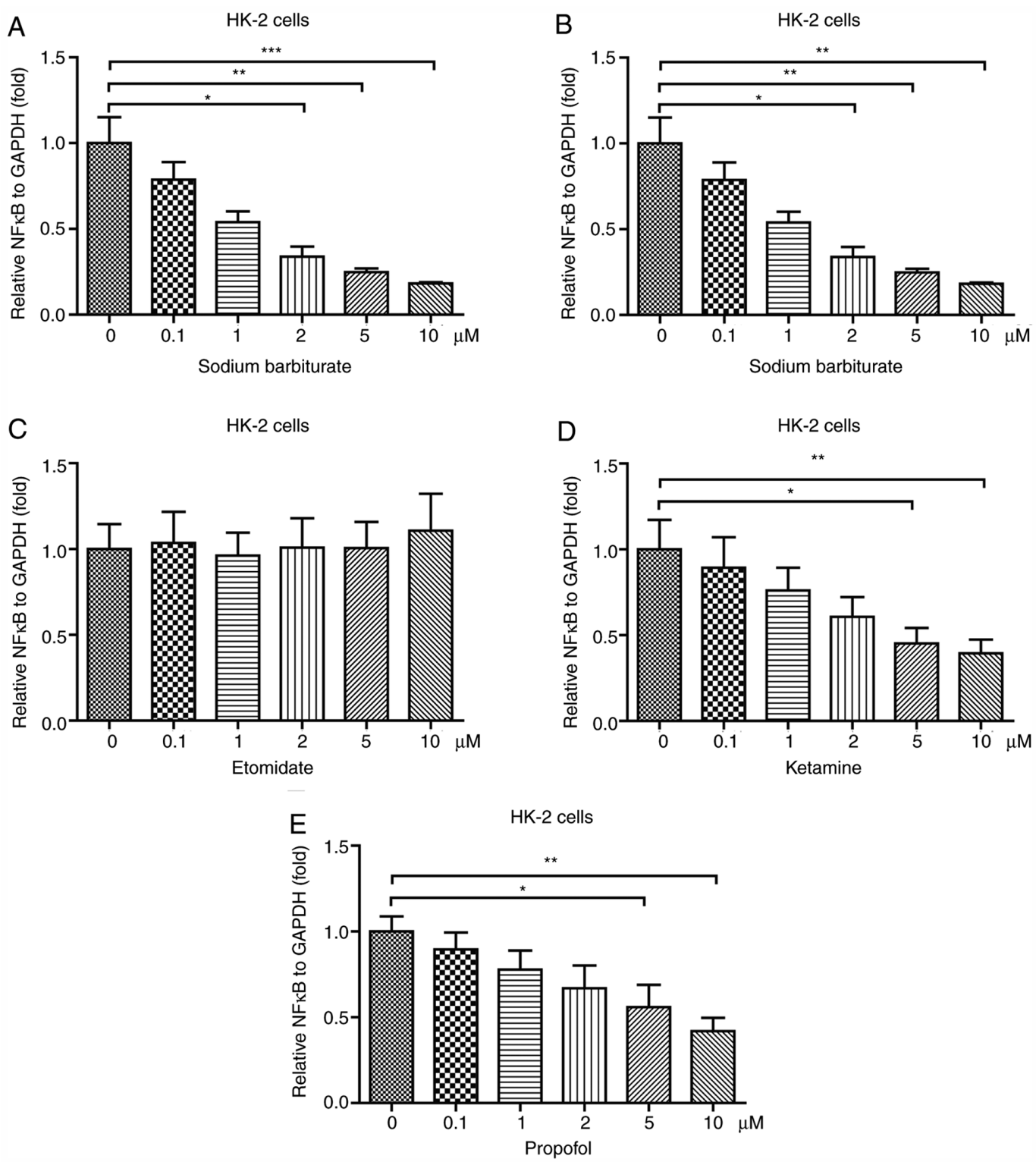

Figure 1. Sodium barbiturate, ketamine and propofol decrease NF- $\mathrm{kB}$ expression in HK-2 cells. Effects of (A) sodium barbiturate, (B) midazolam, (C) etomidate, (D) ketamine and (E) propofol on the mRNA expression levels of NF- $\mathrm{KB}$ in HK-2 cells $(\mathrm{n}=4) .{ }^{*} \mathrm{P}<0.05,{ }^{* * *} \mathrm{P}<0.01$ and ${ }^{* * * *} \mathrm{P}<0.001$.

were subjected to SDS-PAGE (10\% gel) at $110 \mathrm{~V}$, followed by protein transfer to polyvinylidene difluoride membranes on ice at $100 \mathrm{~V}$ for $2 \mathrm{~h}$. The membranes were blocked with $5 \%$ skimmed milk diluted in $\mathrm{ddH}_{2} \mathrm{O}$ at room temperature 

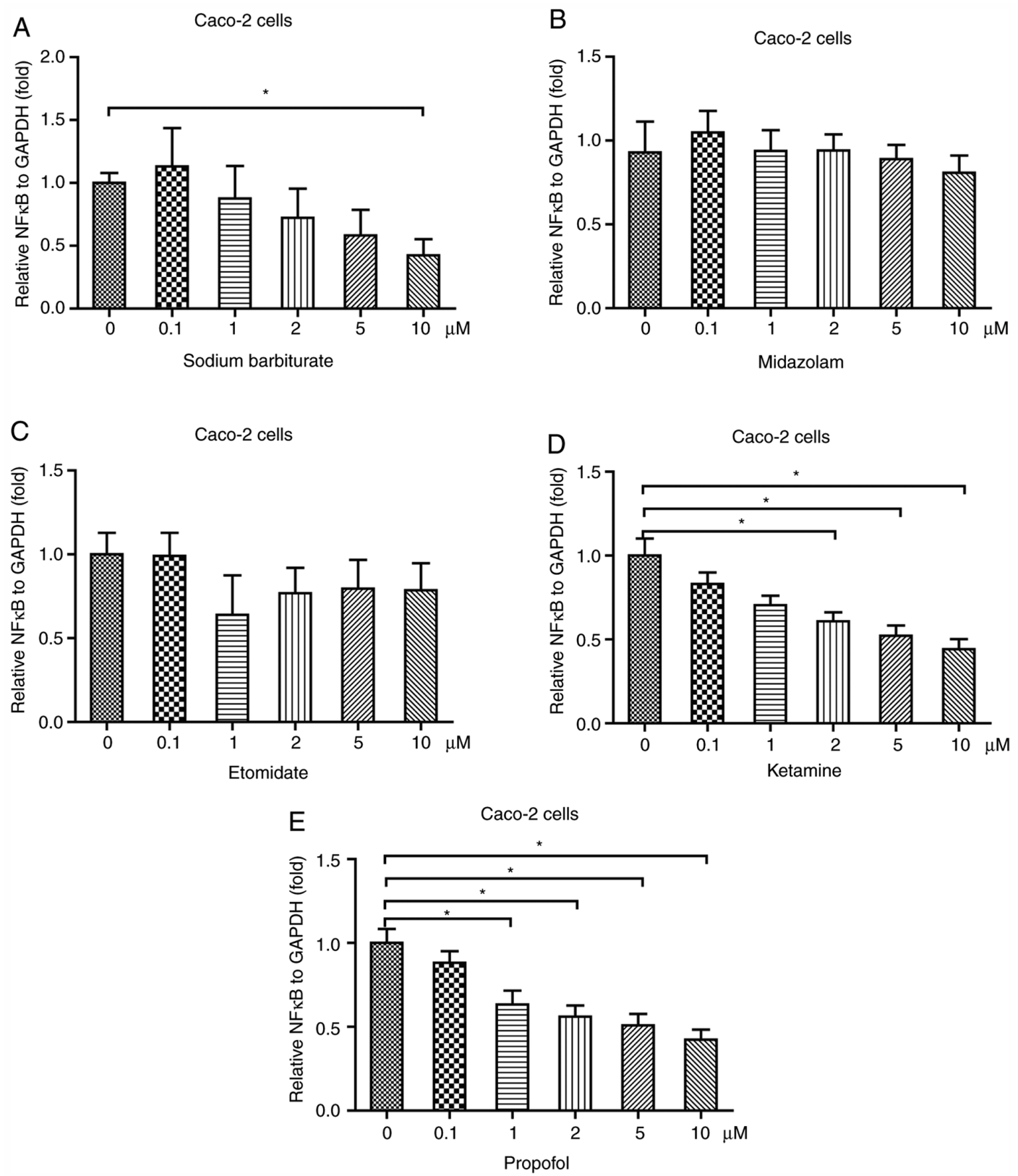

Figure 2. Sodium barbiturate, ketamine and propofol decrease NF-kB expression in Caco-2 cells. Effects of (A) sodium barbiturate, (B) midazolam, (C) etomidate, (D) ketamine and (E) propofol on the mRNA expression levels of NF- $\mathrm{kB}$ in Caco-2 cells ( $\mathrm{n}=4)$. " $\mathrm{P}<0.05$.

for $1 \mathrm{~h}$ and subsequently incubated with rabbit anti-IL-1 $\beta$ (D3U3E; cat. no. 12703), anti-IL-18 (D2F3B; cat. no. 54943) and anti- $\beta$-actin (13E5; cat. no. 4970$)$ antibodies at $4^{\circ} \mathrm{C}$ overnight (all at 1:1,000 dilution; Cell Signaling Technology, Inc.). Then, the membranes were washed three times with PBS supplemented with $0.1 \%$ Tween- 20 for 15 min, followed by an incubation with HRP-conjugated goat anti-rabbit IgG H\&L (1:5,000; cat. no. ab6721; Abcam) for $1 \mathrm{~h}$ at room temperature before washing with PBS with $0.1 \%$ Tween-20 three times for $15 \mathrm{~min} . \beta$-actin was used as the endogenous control. The bands were visualized using Odyssey CLx Imager (LI-COR Biosciences) and quantified using ImageJ software (64-bit Java 1.8.0_172; National Institutes of Health).

Cell Counting Kit-8 (CCK-8). Caco-2, HK-2 and HepG2 cells at a density of $1 \times 10^{4}$ cells/well were seeded into a 96-well-plate (Corning Inc.) and cultured as aforementioned for $24 \mathrm{~h}$. Then, the cells were treated with the aforementioned concentrations of sodium barbiturate, ketamine and propofol for $48 \mathrm{~h}$ at $37^{\circ} \mathrm{C}$. Subsequently, the cells were treated with $10 \mu 1 \mathrm{CCK}-8$ reagent (cat. no. C0037; Beyotime Institute of Biotechnology) for an additional $1 \mathrm{~h}$ at $37^{\circ} \mathrm{C}$ in the dark. The absorbance was measured using a microplate reader (Bio-Rad Laboratories, Inc.) at a wavelength of $450 \mathrm{~nm}$.

Statistical analysis. Statistical analyses were performed using one-way ANOVA followed by Tukey's test using GraphPad Prism software (version 5.0; GraphPad Software, Inc.). Data are presented as the mean \pm SEM of at least three independent experiments. $\mathrm{P}<0.05$ was considered to indicate a statistically significant difference. 

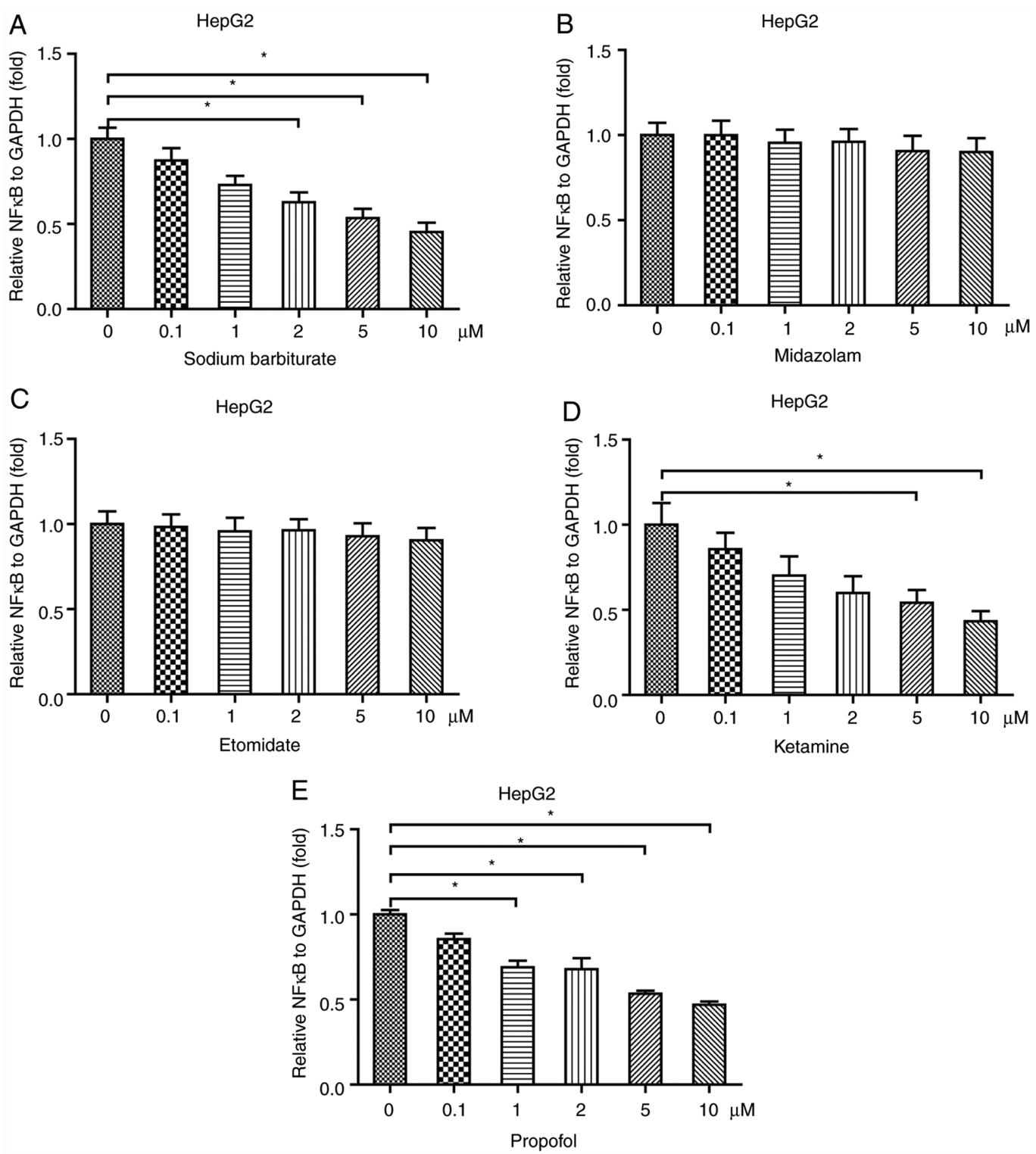

Figure 3. Sodium barbiturate, ketamine and propofol reduce NF-kB expression in HepG2 cells. Effects of (A) sodium barbiturate, (B) midazolam, (C) etomidate, (D) ketamine and (E) propofol on the mRNA expression levels of NF- $\mathrm{kB}$ in HepG2 cells $(\mathrm{n}=4)$. ${ }^{*} \mathrm{P}<0.05$.

\section{Results}

Sodium barbiturate, ketamine and propofol decrease $N F-\kappa B$ expression in $\mathrm{HK}$-2 cells. To investigate the effects of different anesthetic agents on inflammation in the kidney, an immortalized proximal tubule epithelial cell line HK-2 was used. HK-2 cells were treated with different concentrations of five different anesthetic agents, including sodium barbiturate, midazolam, etomidate, ketamine and propofol. The results indicated that sodium barbiturate $(2,5$ and $10 \mu \mathrm{M})$ significantly decreased the mRNA expression levels of NF- $\mathrm{KB}$ in a dose-dependent manner (Fig. 1A). However, midazolam (Fig. 1B) and etomidate (Fig. 1C) did not significantly alter NF- $\kappa B$ mRNA expression levels in HK-2 cells compared with the control group. Ketamine and propofol (5 and $10 \mu \mathrm{M})$ significantly reduced mRNA expression levels of NF- $\kappa \mathrm{B}$ in HK-2 cells (Fig. 1D and E). Collectively, the results suggested that anesthetic agents, including sodium barbiturate, ketamine and propofol, decreased NF- $\mathrm{KB}$ mRNA expression levels in
HK-2 cells, whereas midazolam and etomidate displayed no effect on NF- $\kappa \mathrm{B}$ mRNA expression levels compared with the control cells.

Sodium barbiturate, ketamine and propofol decrease $N F-\kappa B$ expression in Caco-2 cells. The intestine is a location where inflammation often occurs (23). To investigate the effects of anesthetic agents on inflammation in the intestine, a commonly used intestinal cell line (Caco-2) was used $(12,24)$. The results indicated that $10 \mu \mathrm{M}$ sodium barbiturate significantly decreased the mRNA expression levels of NF- $\mathrm{\kappa B}$ in Caco-2 cells (Fig. 2A). Similar to in HK-2 cells, in Caco-2 cells, the results suggested that midazolam (Fig. 2B) and etomidate (Fig. 2C) did not significantly alter the mRNA expression levels of NF- $\kappa$ B. At 2, 5 and $10 \mu \mathrm{M}$, ketamine significantly decreased NF- $\mathrm{kB}$ mRNA expression levels in Caco-2 cells in a dose-dependent manner (Fig. 2D). Moreover, at 1, 2, 5 and $10 \mu \mathrm{M}$, propofol significantly reduced the mRNA expression levels of NF- $\mathrm{KB}$ in HK-2 cells in a dose-dependent manner 
A

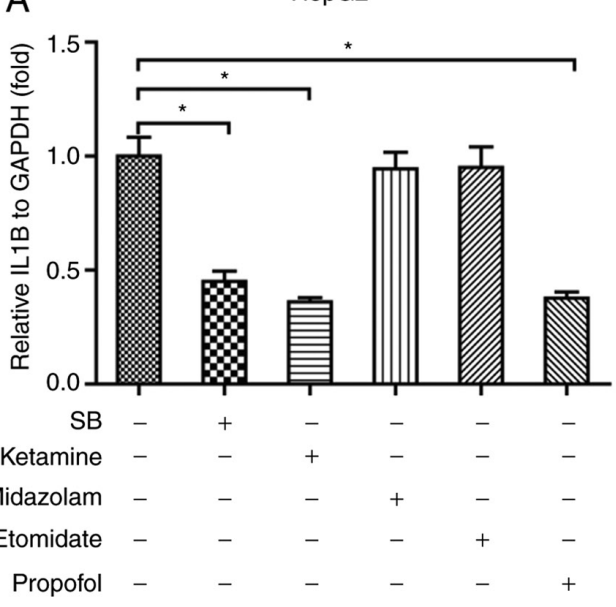

C

Caco-2 cells

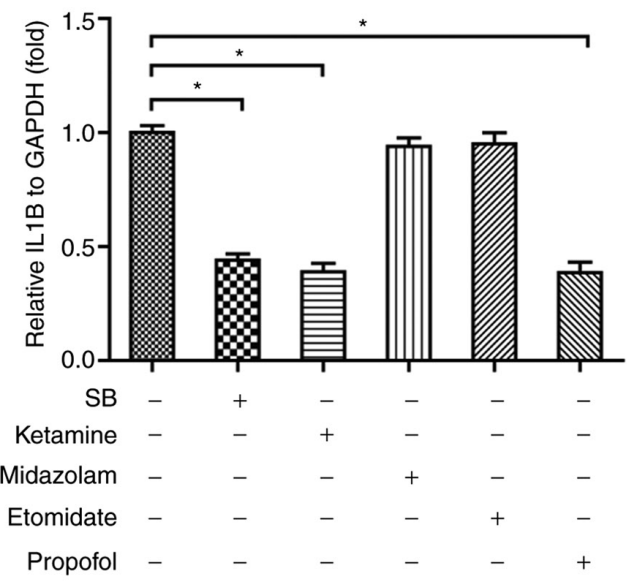

$\mathrm{E}$

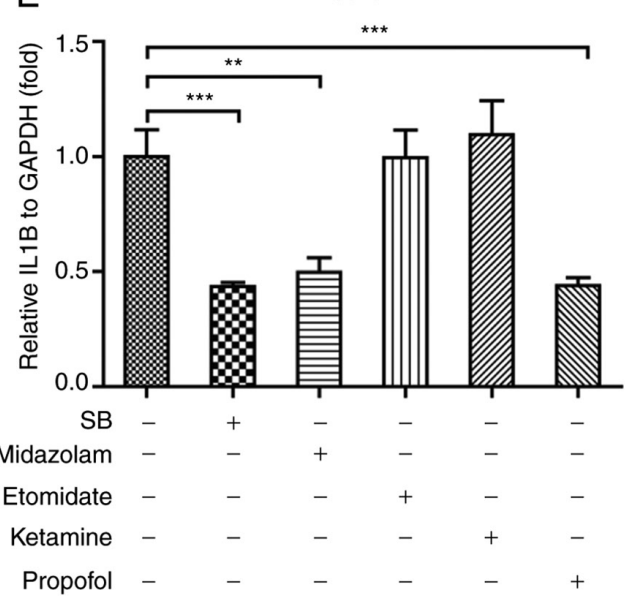

B

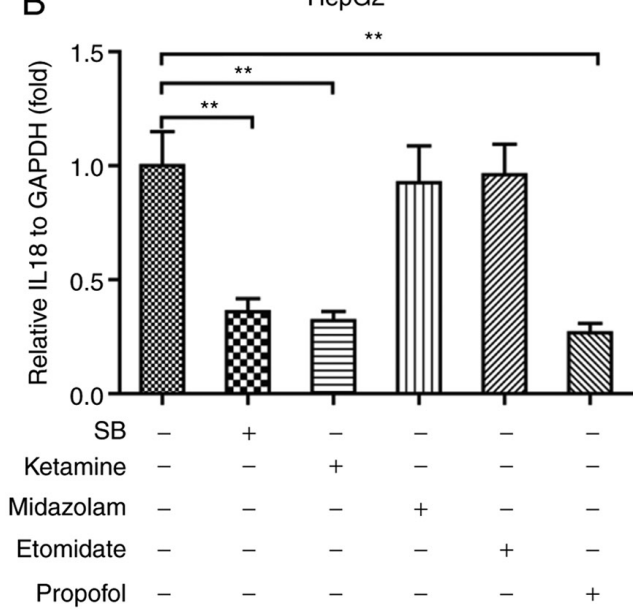

D

Caco-2 cells

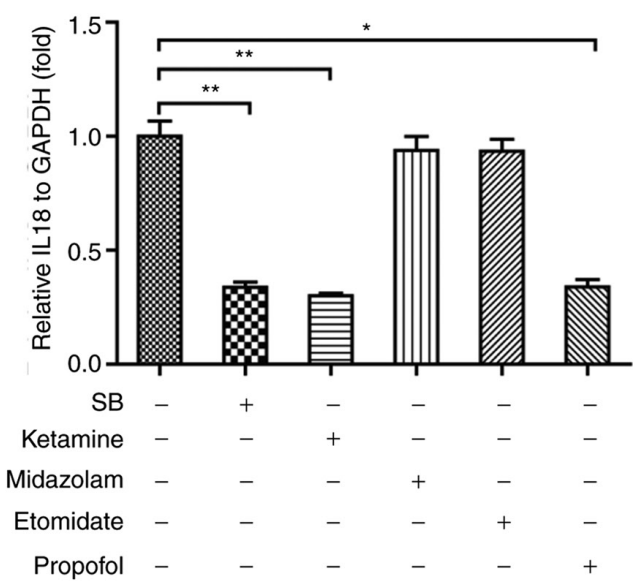

$\mathrm{F}$

HK-2 cells

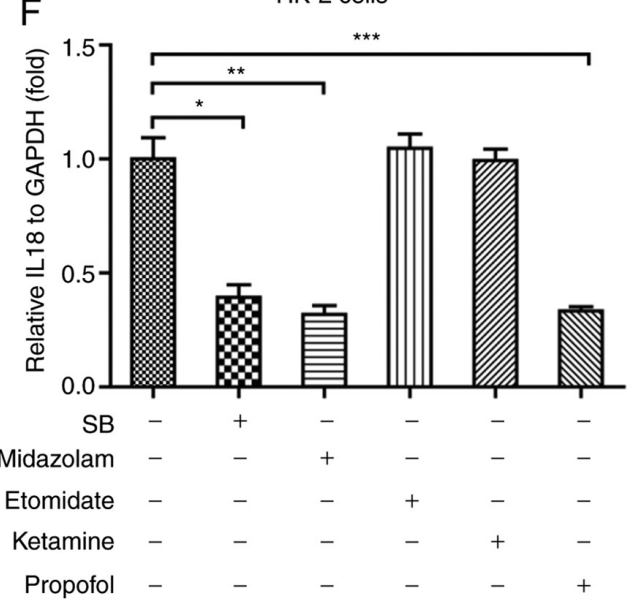

Figure 4. SB, ketamine and propofol inhibit mRNA expression of NF- $\mathrm{kB}$ downstream cytokines in the three cell lines. Effects of anesthetic agents on (A) IL-1 $\beta$ and (B) IL-18 mRNA levels in HepG2 cells, (C) IL-1 $\beta$ and (D) IL-18 mRNA levels in Caco-2 cells, and (E) IL-1 $\beta$ and (F) IL-18 mRNA levels in HK-2 cells. $\mathrm{n}=4 .{ }^{*} \mathrm{P}<0.05,{ }^{* * *} \mathrm{P}<0.01$ and ${ }^{* * * *} \mathrm{P}<0.001$. SB, sodium barbiturate.

(Fig. 2E). Therefore, the results indicated that anesthetic agents, including sodium barbiturate, ketamine and propofol, rather than midazolam and etomidate, decreased the mRNA expression levels of NF- $\mathrm{KB}$ in Caco-2 cells.

Sodium barbiturate, ketamine and propofol reduce $N F-\kappa B$ expression in HepG2 cells. The liver is also an important organ where inflammation may occur (25). To examine the effects of anesthetic agents on inflammation in the liver, a liver cell line HepG2 was treated with different concentrations of sodium barbiturate, midazolam, etomidate, ketamine and propofol. Sodium barbiturate $(2,5$ and $10 \mu \mathrm{M})$ significantly decreased the mRNA expression levels of NF- $\kappa \mathrm{B}$ in HepG2 cells (Fig. 3A). Similar to in HK-2 and Caco-2 cells, the results indicated that midazolam (Fig. 3B) and etomidate (Fig. 3C) had no significant effect on the mRNA expression levels of 

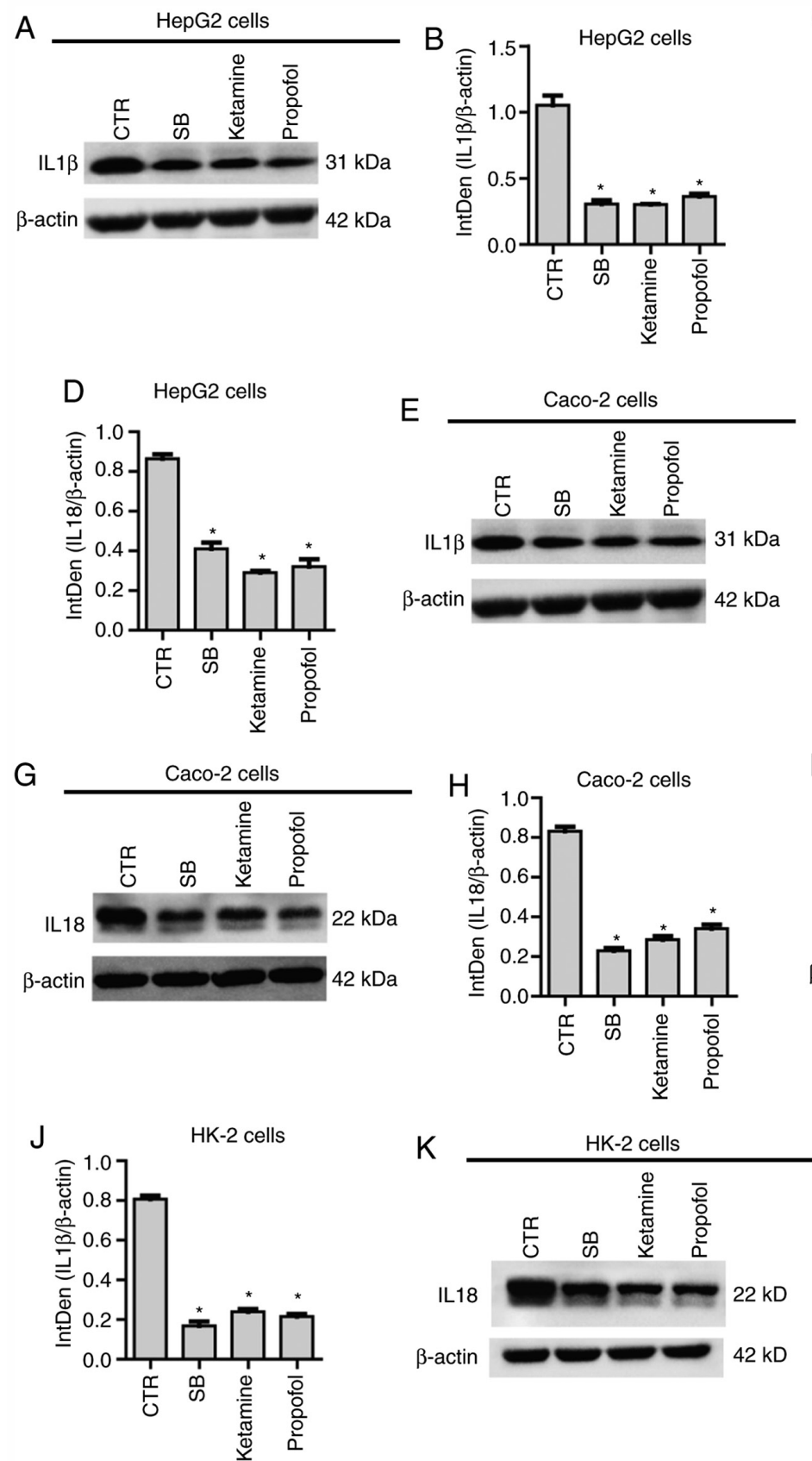

F
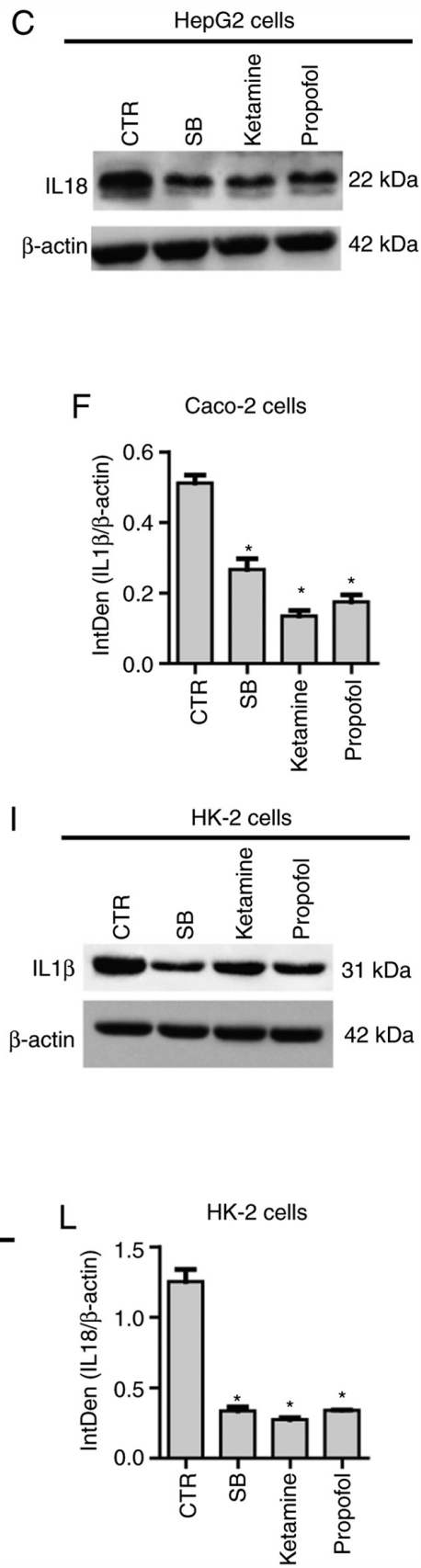

Figure 5. SB, ketamine and propofol inhibit protein levels of NF- $\kappa \mathrm{B}$ downstream cytokines in the three cell lines. The western blotting results indicated that sodium barbiturate, midazolam and propofol decreased the protein expression levels of (A and B) IL-1 $\beta$ and (C and D) IL-18 in HepG2 cells, (E and F) IL-1 $\beta$ and (G and H) IL-18 in Caco-2 cells, and (I and J) IL-1 $\beta$ and (K and L) IL-18 in HK-2 cells. $\mathrm{n}=3$. ${ }^{*} \mathrm{P}<0.05$ vs. CTR. SB, sodium barbiturate; CTR, control; IntDen, Integrated Density.

NF- $\kappa \mathrm{B}$ in HepG2 cells. Ketamine (5 and $10 \mu \mathrm{M})$ significantly decreased NF-kB mRNA expression levels in HepG2 cells in a dose-dependent manner (Fig. 3D). Propofol (1,2, 5 and $10 \mu \mathrm{M}$ ) significantly reduced the mRNA expression levels of $\mathrm{NF}-\mathrm{kB}$ in HepG2 cells in a dose-dependent manner (Fig. 3E). Collectively, the results indicated that anesthetic agents, including sodium barbiturate, ketamine and propofol, but not midazolam and etomidate, decreased the mRNA expression levels of NF-kB in HepG2 cells.

Sodium barbiturate, ketamine and propofol downregulate $N F-\kappa B$ downstream cytokines in the three cell lines. The $\mathrm{NF}-\mathrm{KB}$ signaling pathway serves a central role in regulating inflammatory activities in the body, and can activate a variety of downstream cytokines, including IL1 $\beta$ and IL18, to result in inflammation (26). To further verify the effects of anesthetic agents on inflammation, the effects of sodium barbiturate, midazolam, etomidate, ketamine and propofol on IL-1 $\beta$ and IL-18 expression levels were assessed in the three different cell lines. Sodium barbiturate, ketamine and propofol significantly decreased the mRNA expression levels of IL-1 $\beta$ (Fig. 4A) and IL-18 (Fig. 4B) in HepG2 cells, which was consistent with the observations that the three anesthetic agents downregulated NF- $\kappa \mathrm{B}$ expression. As in HepG2 cells, sodium barbiturate, ketamine and propofol, but not midazolam and etomidate, significantly reduced the mRNA 

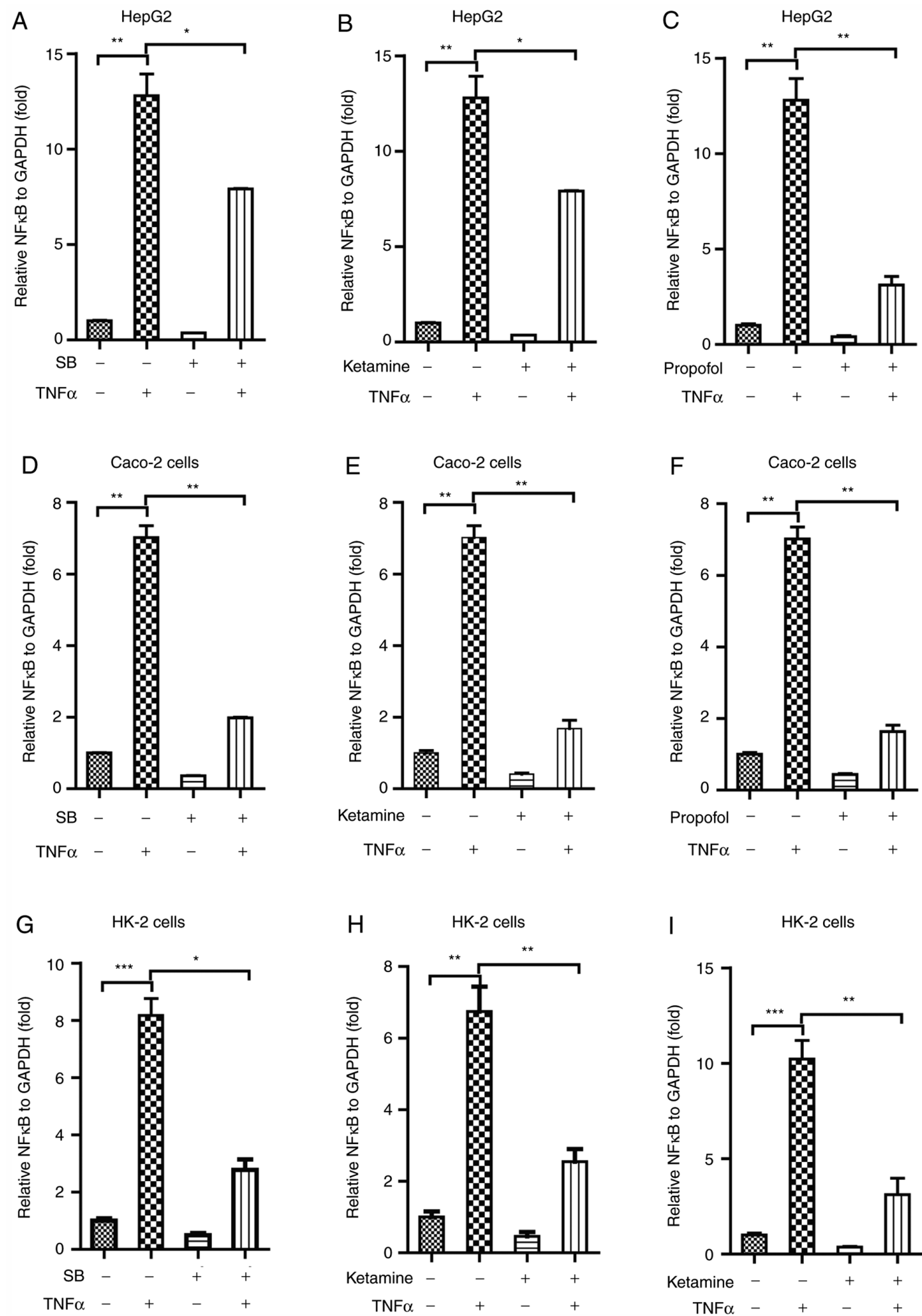

I

HK-2 cells

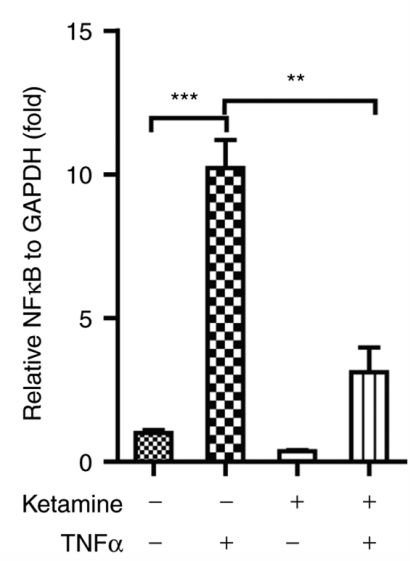

Figure 6. Sodium barbiturate, ketamine and propofol inhibit TNF $\alpha$-mediated increase in NF- $\kappa B$ expression in the three cell lines. Effect of (A) SB, (B) ketamine and (C) propofol on TNF $\alpha$-mediated NF- $\kappa$ B expression in HepG2 cells. Effect of (D) SB, (E) ketamine and (F) propofol on TNF $\alpha$-mediated NF- $\mathrm{BB}$ expression in Caco-2 cells. Effect of $(\mathrm{G}) \mathrm{SB},(\mathrm{H})$ ketamine and (I) propofol on TNF $\alpha$-mediated NF-kB expression in HK-2 cells $(\mathrm{n}=4)$. ${ }^{*} \mathrm{P}<0.05,{ }^{* *} \mathrm{P}<0.01$ and ${ }^{* * * *} \mathrm{P}<0.001$ $\mathrm{SB}$, sodium barbiturate.

expression levels of IL-1 $\beta$ (Fig. 4C) and IL-18 (Fig. 4D) in Caco-2 cells. Finally, the results indicated that sodium barbiturate, ketamine and propofol, but not midazolam and etomidate, significantly decreased the mRNA expression levels of IL-1 $\beta$ (Fig. 4E) and IL-18 (Fig. 4F) in HK-2 cells. To further verify the effects of ketamine, midazolam and propofol on IL-1 $\beta$ and IL-18 expression levels, western blotting was performed. The results indicated that sodium barbiturate, midazolam and propofol decreased the protein expression levels of IL-1 $\beta$ (Fig. 5A and B) and IL-18 (Fig. 5C and D) in HepG2 cells. In parallel, sodium barbiturate, midazolam and propofol decreased the protein expression 

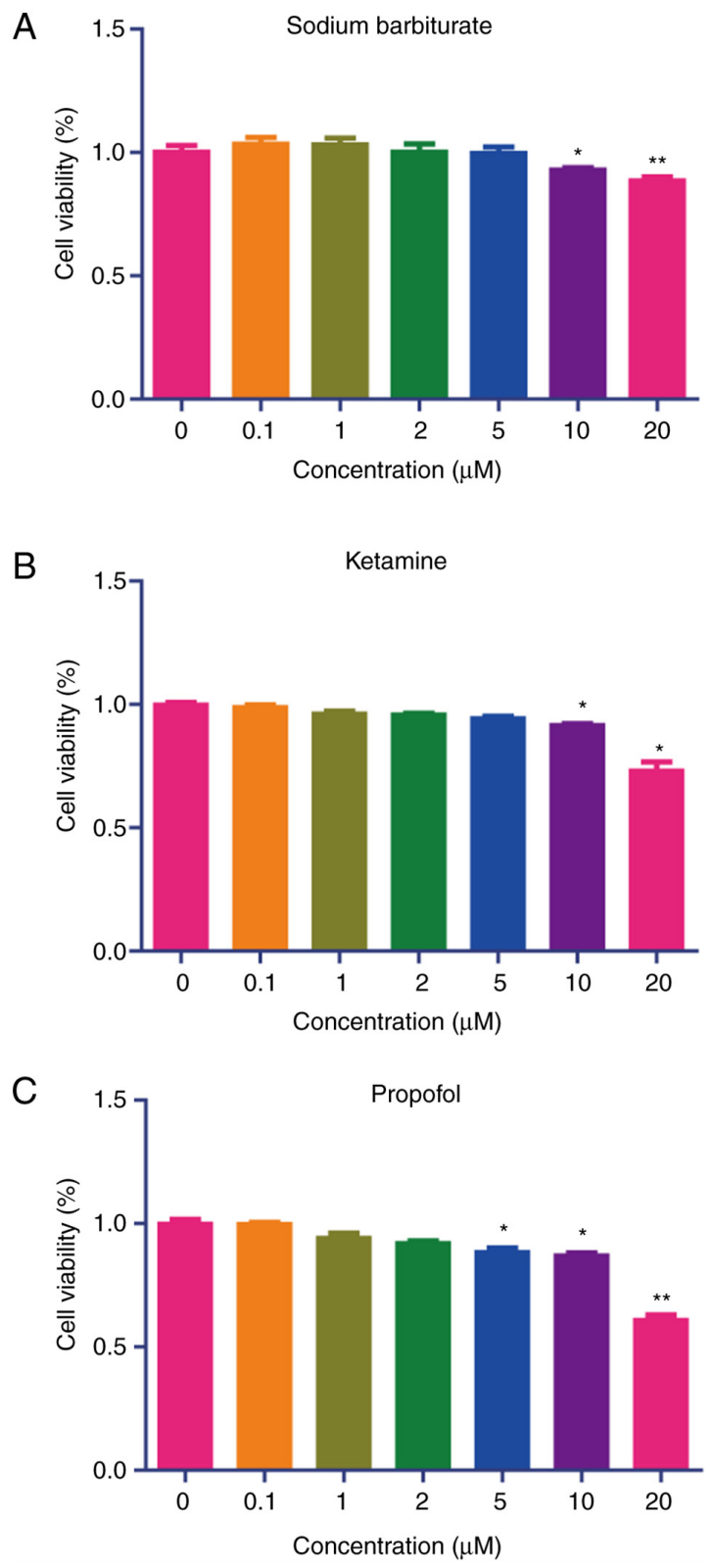

Figure 7. Cell viability following treatment with sodium barbiturate, ketamine and propofol in HepG2, Caco-2 and HK-2 cells. Viability of (A) HepG2 cells, (B) $\mathrm{Caco} 2$ cells and (C) $\mathrm{HK}-2$ cells treated with sodium barbiturate. ${ }^{*} \mathrm{P}<0.05$ and ${ }^{* *} \mathrm{P}<0.01$ vs. $0 \mu \mathrm{M}$.

levels of IL-1 $\beta$ (Fig. 5E and F) and IL18 (Fig. 5G and H) in Caco-2 cells. Similarly, sodium barbiturate, midazolam and propofol decreased the protein expression levels of IL-1 $\beta$ (Fig. 5I and J) and IL-18 (Fig. 5K and L) in HK-2 cells. Therefore, the results indicated that sodium barbiturate, ketamine and propofol suppressed inflammation in the three different cell lines used in the present study.

Sodium barbiturate, ketamine and propofol inhibit $T N F \alpha$-mediated activation of $N F-\kappa B$ signaling in the three different cell lines. TNF- $\alpha$ is an activator of inflammation (27). To further investigate the effects on anesthetic agents on inflammation, cells were co-treated with TNF- $\alpha$ and sodium barbiturate, ketamine or propofol. The three aforementioned anesthetic agents were used as the results indicated that these agents significantly reduced the expression levels of NF- $\kappa \mathrm{B}$ and its downstream effectors. TNF $\alpha(100 \mathrm{nM})$ markedly increased the mRNA expression level of $\mathrm{NF}-\kappa \mathrm{B}$ in HepG2 cells, as determined using RT-qPCR (Fig. 6A-C). Of note, sodium barbiturate (Fig. 6A), ketamine (Fig. 6B) and propofol (Fig. 6C) significantly inhibited $\mathrm{TNF} \alpha$-mediated $N F-\kappa \mathrm{B}$ expression in HepG2 cells. Similarly, TNFa markedly increased the mRNA expression levels of NF- $\mathrm{BB}$ in Caco-2 cells (Fig. 6D-F), and sodium barbiturate (Fig. 6D), ketamine (Fig. 6E) and propofol (Fig. 6F) significantly inhibited $\mathrm{TNF} \alpha$-mediated $\mathrm{NF}-\kappa \mathrm{B}$ expresion in Caco-2 cells, as determined using RT-qPCR. TNF $\alpha$ significantly increased the mRNA expression levels of NF- $\mathrm{BB}$ in HK-2 cells (Fig. 6G-I), and sodium barbiturate (Fig. 6G), ketamine (Fig. 6H) and propofol (Fig. 6I) significantly inhibited $\mathrm{TNF} \alpha$-mediated $\mathrm{NF}-\kappa \mathrm{B}$ expression in $\mathrm{HK}-2$ cells, as determined using RT-qPCR. Collectively, the results indicated that sodium barbiturate, ketamine and propofol inhibited $\mathrm{TNF} \alpha$-mediated activation of $\mathrm{NF}-\kappa \mathrm{B}$ signaling in HepG2, Caco-2 and HK-2 cells.

Effects of sodium barbiturate, ketamine and propofol on Hep 62 , Caco-2 and HK-2 cell viability. To determine the effects of sodium barbiturate, ketamine and propofol on the viability of HepG2, Caco-2 and HK-2 cells, a CCK-8 assay was performed, and it was indicated that 10 and $20 \mu \mathrm{M}$ sodium barbiturate had slight cytotoxicity on HepG2 and Caco-2 cells, respectively (Fig. 7A and B). Furthermore, $20 \mu \mathrm{M}$ sodium barbiturate exhibited cytotoxicity on HK-2 cells (Fig. 7C). High concentrations (10 and $20 \mu \mathrm{M})$ of ketamine showed significant cytotoxicity on HepG2, Caco-2 and HK-2 cells, respectively (Fig. 7D, E and F). Similarly, 5, 10 and $20 \mu \mathrm{M}$ of propofol showed significant cytotoxicity on HepG2 cells (Fig. 7G). Furthermore, 10 and $20 \mu \mathrm{M}$ propofol produced cytotoxicity on Caco-2 (Fig. 7H), and $20 \mu \mathrm{M}$ propofol produced cytotoxicity on HK-2 cells (Fig. 7I). Thus, low concentrations $(<10 \mu \mathrm{M})$ of sodium barbiturate, ketamine and propofol had minor cytotoxic effects while high concentrations $(\geq 10 \mu \mathrm{M})$ had significant effects on the viability of HepG2, Caco-2 and HK-2 cells.

\section{Discussion}

The association between surgical procedures and inflammation has received increasing attention (28). Since anesthetic agents are widely used during surgical procedures to manage the pain and comfort of patients, the effects of anesthetic agents on inflammation have received increasing attention. Therefore, the present study investigated the effects of five commonly used anesthetic agents, including sodium barbiturate, midazolam, etomidate, ketamine and propofol, on inflammation in Caco-2, HK-2 and HepG2 cells. The results indicated that three out of the five anesthetic agents, sodium barbiturate, ketamine and propofol, significantly decreased the expression levels of NF- $\kappa \mathrm{B}$ and its downstream cytokines, including IL-1 $\beta$ and IL-18, in the three cell lines. Moreover, the results indicated that sodium barbiturate, ketamine and propofol inhibited $\mathrm{TNF} \alpha$-mediated activation of $\mathrm{NF}-\kappa \mathrm{B}$ signaling in HepG2, Caco-2 and HK-2 cells. The present study provided novel insight into the molecular mechanisms underlying anesthetic agent-mediated regulation of inflammation 
and may aid in selecting an appropriate anesthetic agent for surgical procedures.

Surgery can cause inflammation, for example, it was reported that colorectal surgery often causes systemic inflammatory response syndrome, which may cause post-operative morbidity and mortality (28). The pathogenesis underlying inflammation induced by surgery is not completely understood. Numerous anesthetic agents are used in surgical procedures. Several studies have demonstrated that certain anesthetic agents are linked to inflammation. Getachew et al (29) reported that ketamine exerted antidepressant and anti-inflammatory effects via interacting with specific gut bacteria in rats. Ketamine was reported to control innate immunity in the body and regulate the functions of a number of cellular effectors in the inflammatory reaction (30). Chang et al (31) reported that ketamine could affect macrophages to suppress $\mathrm{NF}-\kappa \mathrm{B}$-mediated responses to lipopolysaccharide (LPS). Chang et al (32) also reported that ketamine inhibited hypoxia-induced inflammatory responses in late-gestation ovine fetal kidney cortex. In the present study, ketamine markedly decreased $\mathrm{NF}-\kappa \mathrm{B}$ expression in kidney, intestine and liver cell lines, and further downregulated the expression levels of NF- $\kappa \mathrm{B}$ downstream cytokines, which was consistent with previous reports. The present study also indicated that ketamine significantly suppressed $\mathrm{TNF} \alpha$-mediated activation of $\mathrm{NF}-\kappa \mathrm{B}$ signaling in kidney, intestine and liver cell lines. The results of the present study demonstrated the inhibitory effects of ketamine on inflammation. The kidney, intestine and liver contain rich immune cells, which often generate immune reactions in response physiological changes (33). The results of the present study may aid with the identification of a suitable anesthetic agent for surgical procedures on the kidney, intestine and liver.

Propofol has been used in surgery for a number of years (34). Accumulating evidence demonstrated that propofol exerted regulatory effects on inflammation. Jia et al (35) confirmed that propofol could suppress LPS-induced inflammation via the PI3K signaling pathway in microglia. Jia et al (35) reported that propofol suppressed the secretion of cytokines, including IL8, IL6 and TNF $\alpha$, in LPS-treated RAW 264.7 cells. Consistently, the present study indicated that propofol downregulated the expression levels of TNF $\alpha$, IL1 $\beta$ and IL18 in Caco-2, HK-2 and HepG2 cells. The results also indicated that propofol inhibited $\mathrm{TNF} \alpha$-mediated activation of $\mathrm{NF}-\kappa \mathrm{B}$ signaling in the three cell lines.

Furthermore, the present study suggested that sodium barbiturate exerted anti-inflammatory effects in different types of cells. A previous study reported that a barbituric acid derivative exerted an inhibitory effect on the $\mathrm{NF}-\kappa \mathrm{B}$ signaling pathway in hepatic stellate cells (36). In addition, O'Sullivan et al (37) reported that dinitrate-barbiturate served as an anti-inflammatory agent, which could be used for the treatment of inflammatory bowel disease.

It has been reported that several anesthetic agents exert immune regulatory effects in in vitro models. However, the present study had a number of limitations: i) There are other types of anesthetic agents in addition to sodium barbiturate, midazolam, etomidate, ketamine and propofol, thus, screening the effects of a large number of anesthetic agents on inflammation to obtain a profile of the effects of anesthetic agents on immunity is important; ii) cell line models are less reliable compared with more advanced in vitro models, such as organoid models (38), therefore, validating the results of the present study in more advanced organoids is required; and iii) although the preliminary mechanism underlying the effects of anesthetic agents on inflammation was identified in the present study, future studies should investigate the precise mechanism of action.

In conclusion, the inflammatory reaction serves a key role in maintaining body homeostasis and survival, especially in the context of surgical procedures (39). Moreover, three out of the five anesthetic agents, including sodium barbiturate, ketamine and propofol, displayed anti-inflammatory effects in kidney, intestine and liver cells. Midazolam and etomidate did not display significant effects on inflammation in kidney, intestine and liver cells. Sodium barbiturate, ketamine and propofol decreased $\mathrm{TNF} \alpha$-mediated effects on inflammatory gene expression levels. The results of the present study provide further understanding of the effects of anesthetic agents on inflammation and may aid in selecting a suitable anesthetic agent in surgical procedures.

\section{Acknowledgements}

Not applicable.

\section{Funding}

No funding was received.

\section{Availability of data and materials}

The datasets used and/or analysed during the current study are available from the corresponding author on reasonable request.

\section{Authors' contributions}

WL and $\mathrm{XH}$ contributed to study conception, design and management. WL, YL, TT, HX and LJ performed the experiments and collected and analyzed the data. WL contributed to manuscript writing and draft preparation. XH contributed to manuscript revision. All authors read and approved the final manuscript.

\section{Ethics approval and consent to participate}

Not applicable.

\section{Patient consent for publication}

Not applicable.

\section{Competing interests}

The authors declare that they have no competing interests.

\section{References}

1. Slupe AM and Kirsch JR: Effects of anesthesia on cerebral blood flow, metabolism, and neuroprotection. J Cereb Blood Flow Metab 38: 2192-2208, 2018.

2. Armstrong R, Riaz S, Hasan S, Iqbal F, Rice T and Syed N Mechanisms of anesthetic action and neurotoxicity: Lessons from molluscs. Front Physiol 8: 1138, 2018. 
3. Kaewjiaranai T, Srisatjaluk RL, Sakdajeyont W, Pairuchvej V and Wongsirichat N: The efficiency of topical anesthetics as antimicrobial agents: A review of use in dentistry. J Dent Anesth Pain Med 18: 223-233, 2018

4. MacIver MB: Anesthetic agent-specific effects on synaptic inhibition. Anesth Analg 119: 558-569, 2014.

5. Wagner M, Ryu YK, Smith SC, Patel P and Mintz CD: Review: Effects of anesthetics on brain circuit formation. J Neurosurg Anesthesiol 26: 358-362, 2014

6. Tanaka DM, Romano MM, Carvalho EE, Oliveira LF, Souza HC, Maciel BC, Salgado HC, Fazan-Junior R and Simoes MV: Effect of different anesthetic agents on left ventricular systolic function assessed by echocardiography in hamsters. Braz J Med Biol Res 49: e5294, 2016.

7. Braz MG and Karahalil B: Genotoxicity of anesthetics evaluated in vivo (animals). Biomed Res Int 2015: 280802, 2015.

8. Kunnumakkara AB, Sailo BL, Banik K, Harsha C, Prasad S, Gupta SC, Bharti AC and Aggarwal BB: Chronic diseases, inflammation, and spices: How are they linked? J Transl Med 16: $14,2018$.

9. Saxena S and Maze M: Impact on the brain of the inflammatory response to surgery. Presse Med 47: e73-e81, 2018.

10. Chiang N, Schwab JM, Fredman G, Kasuga K, Gelman S and Serhan CN: Anesthetics impact the resolution of inflammation. PLoS One 3: e1879, 2008.

11. Kim R: Effects of surgery and anesthetic choice on immunosuppression and cancer recurrence. J Transl Med 16: 8, 2018.

12. Livak KJ and Schmittgen TD: Analysis of relative gene expression data using real-time quantitative PCR and the 2(-Delta Delta C(T)) method. Methods 25: 402-408, 2001

13. Kampfer AAM, Urban P, Gioria S, Kanase N, Stone V and Kinsner-Ovaskainen A: Development of an in vitro co-culture model to mimic the human intestine in healthy and diseased state. Toxicol In Vitro 45: 31-43, 2017.

14. Ryan MJ, Johnson G, Kirk J, Fuerstenberg SM, Zager RA and Torok-Storb B: HK-2: An immortalized proximal tubule epithelial cell line from normal adult human kidney. Kidney Int 45 48-57, 1994.

15. Wang L, Liu N, Xue X and Zhou S: The effect of overexpression of the enhancer of zeste homolog 1 (EZH1) gene on aristolochic acid-induced injury in HK-2 human kidney proximal tubule cells in vitro. Med Sci Monit 25: 801-810, 2019.

16. Zhang Y, Wang C, Yu B, Jiang JD and Kong WJ: Gastrodin protects against ethanol-induced liver injury and apoptosis in HepG2 cells and animal models of alcoholic liver disease. Biol Pharm Bull 41: 670-679, 2018.

17. Shah UK, Mallia JO, Singh N, Chapman KE, Doak SH and Jenkins GJS: Reprint of: A three-dimensional in vitro HepG2 cells liver spheroid model for genotoxicity studies. Mutat Res Genet Toxicol Environ Mutagen 834: 35-41, 2018

18. Saito T, Kurashima A, Oda T, Aoki S, Endo H, Nashimoto T and Yamada R: Quantitative analysis of plasma concentration of barbiturate for diagnosis of brain death. No Shinkei Geka 30: 593-599, 2002 (In Japanese).

19. Steiner C, Steurer MP, Mueller D, Zueger M and Dullenkopf A: Midazolam plasma concentration after anesthesia premedication in clinical routine-an observational study: Midazolam plasma concentration after anesthesia premedication. BMC Anesthesiol 16: 105, 2016.

20. Hebron BS: Plasma concentrations of etomidate during an intravenous infusion over 48 hours. Anaesthesia 38 (Suppl): S39-S43, 1983.

21. Lam E, Rochani A, Kaushal G, Thoma BN, Tanjuakio J, West FM and Hirose $\mathrm{H}$ : Pharmacokinetics of ketamine at dissociative doses in an adult patient with refractory status asthmaticus receiving extracorporeal membrane oxygenation therapy. Clin Ther 41: 994-999, 2019.
22. Casati A, Fanelli G, Casaletti E, Cedrati V, Veglia F and Torri G: The target plasma concentration of propofol required to place laryngeal mask versus cuffed oropharyngeal airway. Anesth Analg 88: 917-920, 1999.

23. Chen S, Feng C, Fang Y, Zhou X, Xu L, Wang W, Kong X, Peppelenbosch MP, Pan Q and Yin Y: The eukaryotic translation initiation factor $4 \mathrm{~F}$ complex restricts rotavirus infection via regulating the expression of IRF1 and IRF7. Int J Mol Sci 20: 1580, 2019.

24. Yin Y, Bijvelds M, Dang W, Xu L, van der Eijk AA, Knipping K, Tuysuz N, Dekkers JF, Wang Y, de Jonge J, et al: Modeling rotavirus infection and antiviral therapy using primary intestinal organoids. Antiviral Res 123: 120-131, 2015.

25. Koyama $\mathrm{Y}$ and Brenner DA: Liver inflammation and fibrosis. J Clin Invest 127: 55-64, 2017.

26. Chen Z, Amro EM, Becker F, Holzer M, Rasa SMM, Njeru SN, Han B, Di Sanzo S, Chen Y, Tang D, et al: Cohesin-mediated NF-kB signaling limits hematopoietic stem cell self-renewal in aging and inflammation. J Exp Med 216: 152-175, 2019.

27. Hakim MS, Ding S, Chen S, Yin Y, Su J, van der Woude CJ, Fuhler GM, Peppelenbosch MP, Pan Q and Wang W: TNF- $\alpha$ exerts potent anti-rotavirus effects via the activation of classical NF-kB pathway. Virus Res 253: 28-37, 2018.

28. Wolfer AM, Scott AJ, Rueb C, Gaudin M, Darzi A, Nicholson JK, Holmes E and Kinross JM: Longitudinal analysis of serum oxylipin profile as a novel descriptor of the inflammatory response to surgery. J Transl Med 15: 83, 2017.

29. Getachew B, Aubee JI, Schottenfeld RS, Csoka AB, Thompson KM and Tizabi Y: Ketamine interactions with gut-microbiota in rats: Relevance to its antidepressant and anti-inflammatory properties. BMC Microbiol 18: 222, 2018.

30. Yin Y, Metselaar HJ, Sprengers D, Peppelenbosch MP and Pan Q: Rotavirus in organ transplantation: Drug-virus-host interactions. Am J Transplant 15: 585-593, 2015.

31. Chang EI, Zarate MA, Rabaglino MB, Richards EM, Arndt TJ, Keller-Wood M and Wood CE: Ketamine decreases inflammatory and immune pathways after transient hypoxia in late gestation fetal cerebral cortex. Physiol Rep 4: e12741, 2016.

32. Chang EI, Zarate MA, Rabaglino MB, Richards EM, Keller-Wood $M$ and Wood CE: Ketamine suppresses hypoxia-induced inflammatory responses in the late-gestation ovine fetal kidney cortex. J Physiol 594: 1295-1310, 2016.

33. Sahinovic MM, Struys M and Absalom AR: Clinical pharmacokinetics and pharmacodynamics of propofol. Clin Pharmacokinet 57: 1539-1558, 2018.

34. Luo J, Huang B, Zhang Z, Liu M and Luo T: Delayed treatment of propofol inhibits lipopolysaccharide-induced inflammation in microglia through the PI3K/PKB pathway. Neuroreport 29: 839-845, 2018.

35. Jia J, Sun Y, Hu Z, Li Y and Ruan X: Propofol inhibits the release of interleukin-6, 8 and tumor necrosis factor- $\alpha$ correlating with high-mobility group box 1 expression in lipopolysaccharides-stimulated RAW 264.7 cells. BMC Anesthesiol 17: 148, 2017.

36. Wang YH, Suk FM, Liu CL, Chen TL, Twu YC, Hsu MH and Liao YJ: Antifibrotic effects of a barbituric acid derivative on liver fibrosis by blocking the NF-kB signaling pathway in hepatic stellate cells. Front Pharmacol 11: 388, 2020.

37. O'Sullivan S, Wang J, Pigott MT, Docherty N, Boyle N, Lis SK, Gilmer JF and Medina C: Inhibition of matrix metalloproteinase- 9 by a barbiturate-nitrate hybrid ameliorates dextran sulphate sodium-induced colitis: Effect on inflammation-related genes. Br J Pharmacol 174: 512-524, 2017.

38. Yin YB, de Jonge HR, Wu X and Yin YL: Mini-gut: A promising model for drug development. Drug Discov Today 24: 1784-1794, 2019.

39. Staff N, Engelstad J, Klein C, Amrami K, Spinner R, Dyck P, Warner M, Warner M and Dyck P: Post-surgical inflammatory neuropathy. Brain 133: 2866-2880, 2010. 